\title{
IV.-Notes on the Geology of the North Coast of the St. Lawrence.
}

\author{
By Capt. BAYFIELD, R.N. F.R.A.S.
}

Communicated by G. B. Greenough, Esq. P.G.S.

[Read Nov. 20th, 1833.]

1. ON presenting a suite of specimens to the Geological Society from a long line of coast, which is scarcely more known in Canada than in Europe, being seldom visited except by fur traders and fishermen, I hope a few remarks upon the structure of the country, will not be deemed devoid of interest, though my official duties did not allow of a minute investigation.

The district between Quebec and the river Saguenay, particularly about Murray Bay, has been examined by Dr. Bigsby. The late William Green, Esq. has most ably described the vicinity of Montmorency*; and Lieut. Baddeley of the Royal Engineers, St. Paul's bay and the Saguenay rivert with a minuteness and ability which leave me nothing to add. I shall therefore commence my account at the Saguenay, and proceeding eastward, describe the coast of the river and Gulf of St. Lawrence. I

2. From the Saguenay to Pointe de Monts, a distance of 130 nautical miles $\$$, the hills forming the coast are composed, for the greater part, of varieties of syenitic granite; and the country inland as far as the Falls of the Bersimis river, about 40 miles from the $\mathrm{St}$. Lawrence, in a direction parallel, or nearly so, to the course of the Saguenay, consists of the same formation.

All the valleys and basins between the granitic hills are filled with horizontally stratified deposits of clay, sand and gravel, sometimes 200 or 300 feet thick; the clay being invariably next the granite, and the gravel generally on the surface. No organic remains having been found, it is difficult to assign to these deposits any relative age I; but as the rivers, tributary both to the St. Lawrence and the Saguenay, have cut sections through them, future investi-

* Transactions of Literary and Historical Society of Quebec, vol. i. p. 181.

† Ibid.vol. i. p. 79. vol. ii. p. 76 . $\quad \ddagger$ Plate V. fig. 1 .

$\$$ The distances in this memoir always mean nautical miles.

T Shells of species, existing at present in the estuary of the St. Lawrence, have been found in banks of similar sand and clay, as will be noticed hereafter (p. 96.).

VOL. V.-SECOND SERIES. 
gations may lead, by the discovery of fossils, to their true history and relative age. I am, however, averse from applying to them the term diluvial, because the regularity of their stratification would seem to be due to a cause less violent and longer continued, than is consistent with our ideas of diluvial action.

These immense deposits abound on all parts of the north coast of the St. Lawrence, which we have visited; nor are they wanting on the south coast. The soil which they supply is by no means good, but is sufficient for the growth of large pines, and may be not altogether unsusceptible of cultivation.

These formations must not, however, be confounded with the alluvial.deposits at the mouths of the rivers, the latter being chiefly due to the currents undermining the soft banks, composed of the former.

Alluvial accumulations of this description, occur extensively at Pointe Mille Vaches and Port Neuf, as well as at the entrance of the Bersimis, Outard, Manicouagan, and other rivers.

The extensive Manicouagan shoals have doubtlessly been formed by the two last rivers, especially the Outard, whose course for eight or nine miles, from the falls to the sea, is through the soft strata just mentioned.

On approaching Outard bay after the time of high water, the sea was of the colour of sand, and had it not been previously ascertained that there were nearly 100 fathoms of water, we should have supposed that a sand bank existed close to the surface of the sea. When the vessel sailed into the discoloured water the effect was very remarkable. She cut through and displaced the thin stratum of comparatively fresh and discoloured water, displaying the clear blue sea beneath, and left a blue line wherever she passed. The discoloured water was ascertained to be derived from the Outard river, charged with sedimentary matter; and was so widely diffused as to cover the whole bay, and the sea for several miles.

3. The same granitic rocks, with stratified deposits in the valleys, and alluvial formations at the entrances of the rivers, compose the coast and country, from Pointe de Monts to the Seven Islands, a distance of 60 miles. The rocks constituting the Seven Islands abound with hornblende.

In the bay of the Seven Islands is a very extensive alluvial formation, elevated only a few feet above the present level of the sea at high water.

Walking inland from the sandy beach, which extends for many miles to the eastward, I counted seven parallel sand ridges in a distance of about a mile; evidently ancient beaches which formed, at different successive epochs, the margin of the sea. The number of these beaches and the nature of the wood which covers them, would seem to show, that those furthest inland are very ancient. On removing the thin covering of vegetable matter, 1 found in several of the ridges, clam shells perfectly similar to those which abound on the present shore. That the beaches were formed by the combined action of the sea and adjacent rivers, continued during an immense period of time, there can be no doubt; and on comparing Des Barres' plan of this bay with our survey, no appre- 
ciable change appears to have taken place in the last 70 years. Whenever excavations have been made in the sand, sufficiently deep to reach below the level of the sea at low water, clay has been met with. In this respect, therefore, these undoubtedly alluvial formations bear a strong resemblance to the deposits in the valleys, basins, and hollows of the granitic hills previously mentioned, and seem to differ from them principally in being much thinner, and in accupying lower levels.

The sandy country continues from the Seven Islands to the river Moisic, a large stream which is full of sand banks, and deposits extensive sandy shoals near its mouth. It is about five leagues from the Seven Islands. About three leagues further eastward, the granitic hills, which to the westward range several miles in rear of the coast, and opposite the islands attain an elevation of 1700 feet, again approach the sea, and form the coast to the Magpie river, a distance of 60 miles.

4. The unstratified rocks of this long line of coast are arranged irregularly, in round-backed hills and ridges, often studded thickly with round knolls. Their elevation above the sea seldom exceeds 1000 feet, being about the same as that of the coast westward of Pointe de Monts, There is a much greater variety in the primitive rocks in this part of the north coast, than in any other further to the westward. Besides the genuine granite, composed of quartz, felspar, and mica, and considered comparatively rare in Canada, there is a peculiar kind of glassy felspar*, not met with by us elsewhere, which forms considerable hills and the coast for many miles. Porphyry was found at the falls of the Manitou river, and 1 believe this is the only locality yet observed in Lower Canada : it passes into syenite. Magnetic iron ore occurs abundantly in veins and beds, associated with the felspar rocks $\dagger$.

5. From the Magpie river to Mingan, the coast is formed of the stratified, argillaceous, and arenaceous deposits, and of the alluvion of the river St. John. The soil is poor, loose, and sandy, but covered with a dense forest of spruce, with a few birch and aspen trees.

Near the river St. John, resting on the clay, is a semi-indurated sandstone in process of forming, by the percolation through the sand, of water strongly impregnated with red oxide of iron.

As my remarks have arrived near the western extremity of the Mingan islands, I shall make a few ouservations upon the coast which has passed in such brief review. Our boats visited every part, and ascended the rivers to their falls, yet no rocks of the transition or secondary classes were observed in situ. Magnetic iron ore is largely and generally disseminated, although

* I do not affirm that this is the glassy felspar of mineralogists; but its cross fracture is highly vitreous. Its laminæ are frequently striated,-a character common in the felspars of the St. Lawrence.

t Most of the specimens in this seetion of the coast, were collected by my assistants'Lieutenant Collins and Mr. Bowen. 
we observed it in the greatest quantity in the portion of the coast which $I$ have last described. When not seen, its existence at no great distance, was indicated by the large quantity of magnetic iron-sand on the beach, and by its effects upon the instruments, used on shore in the survey of the coast. The compass needles were frequently and powerfully disturbed all along the north coast of the St. Lawrence, not only within the limits which $I$ have mentioned, but from Cap Tourment eastward, to the eastern extremity of the Esquimaux islands, and perhaps to the longitude of $60^{\circ}$ west. I must not be understood as confirming the vulgar opinion, that the compasses of vessels sailing up the St. Lawrence, are affected; on the contrary, we observed, that the needles on board the Gulnare, were visibly disturbed in one or two instances only, when the vessel was not more than a mile or a mile and a half from the shore. The strongest case was off Port Neuf, where the beach contains large quantities of magnetic iron sand, and we were not more distant than $1 \frac{1}{2}$ miles, yet even there the disturbance did not exceed four or five degrees; and at double the distance it became insensible.

From the Magpie river to Mingan, the granitic rocks are hid by the alluvion and the superincumbent soft strati. They pier however, through the sand at the entrance of the Mingan river; and afterwarus appear frequently at the margin of the sea, within the Mingan and Esquimaux islands, affording op: portunities, occasionally, of observing their junction with the limestone of which those islands are formed.

6. The Mingan and Esquimaux islands, 29 in number, are situated just to the northward of the $50^{\circ}$ of latitude, and between the $64 \frac{1}{4}^{\circ}$ and $63 \frac{1}{4}^{\circ}$ west Jongitude, or nearly so. They range parallel to the coast from the Perroquets at the west, to St. Genevieve at the east end of the chain, a distance of about forty-three nautical miles. Their not hern points are no where more than three and a half miles from the mainland, and are generally close to it ; while their southern or outer points, do not extend further off the main shore than six and a half or seven miles. The most extensive island is called Large Island, being about ten miles in circumference, and Esquimaux island is not much smaller. The general character of the group is low, the highest points not exceeding perhaps 300 feet above the sea. On the north, east, and west sides, are bold and frequently steep cliffs; but on the south side the outline is low and shelving. In these and other respects, the Mingan and Esquimaux islands resemble the opposite island of Anticosti, from which, at the nearest point, they are distant about $14 \frac{1}{3}$ miles.

Both the groups are entirely calcareous, and the strata dip only a few degrees to the south ward, or a little to the westward of south. The limestone varies much in different parts even of the same island, being sometimes compact, or earthy, or shaly, at others imperfectly crystalline, and occasionally it passes into a calcareous sandstone, in which grains of the minerals composing primitive rocks and fragments of shells, are agglutinated by a calcareous cement. 
The small columnar or prismatic structure was several times observed, precisely similar to specimens, which I have seen, from the limestone of Kingston in Upper Canada. At Betchewun harbour, between Hunting island and the main, we noticed parallel, semi-cylindrical groovings in the limestone, of various dimensions, and diagonal to the direction of the strata. At first we imagined they had been produced by the attrition of boulders drifted by running water; but further observation induced us to think, they were due to structure.

There is plenty of stone fit for the common purposes of building, but we saw none adapted for ornamental architecture. Many of the strata are very hard, and although I do not think very large blocks could be procured, yet the stone appears of excellent quality and stands the weather well.

Masses of flint were found several times on the beaches, and nodules of chert are not uncommon in the limestone, particularly at Harbour island, Mingan, where the nodules are evidently derived. from organic remains. I found Orthoceratites, Encrinites, \&c., completely converted into chert, but with their shapes perfectly retained. In the greater number of these nodules, however, the form of the organic body had bet nearly obliterated, and in many cases it was not perceptible. No metallic minerals were found'n any quantity, but traces of lead, zinc, copper, and iron were observed in all the islands.

In some places there are few or no organic remains, but they are generally abundant. The most common is a species of Ammonites, next Orthocera, and both were seen occasionally of very large size. Encrinites and corals were also numerous, and several kinds of bivalve shells. Unchambered univalves were very rare, as we found only four or five specimens of two kinds. Many of the fossils are similar to those in the limestones of Anticosti, Cape Gaspé, the neighbourhood of Quebec, Kingston in Upper Canada, and the Manatoulin islands in Lake Huron, a circumstance which induces me to think, that these limestones are of the same age. From the organic remains, and all the strata being carbonaceous or bituminous*, I infer also that they are analogous to the mountain limestone of England.

7. On most of the Mingan islands the limestone cliffs have been broken by the waves into columns of various shapes, frequently resembling flower pots, or arched and perforated rocks, \&c. Plate V. fig. 2.

It is extremely worthy of remark, that there are limestone columns and beaches of limestone shingle, or gravel, exactly similar to those now forming, high up on the islands, from thirty to sixty feet, at the lowest estimation, above the present level of the ocean at the highest tides, and far back among the trees, in rear of the present sea beach.

One of thypotheses must, I think, be adopted to account for these appearances :-either the general level of the ocean has fallen or the land has risen. If the latter supposition be the correct one, and I think it by far more probable than the former, the raising of the land cannot have been violently accomplished, for the strata are not disturbed, nor the columns khrown out of the perpendicular; neither can it have been done all at once, but by a succession of gentle movements at different epochs, aeting uniformly over a great extent of country at the same time.

This reasoning is founded upon the following appearances and observations:-The land cannot have been raised by one great operation, because the columns and beaches are at different levels on the same island; and because on groups of flower-pot shaped, or other columns, there are

* The limestone of the Manitoulin Islands is occasionally very bituminous. I have found Orthoceratites from which, when broken, the bitumen flowed like tar. 
marks of the sea having remained for a considerable time at different. levels; to which parallel beaches of limestone shingle correspond.

I imagined, at first, that the peculiar shapes of these natural columns might be the effect of atmospherical agents, and the unequal hardness and consequent power to resist that effect, in the different alternating strata of limestone. Observation however soon convinced me, that these agents are incapable of producing such effects. They may and do wear away the cliffs rapidly, aided by the expansive power of freezing water, in a climate whose winter temperature is solow; and if the cliff be composed of strata of a nature to be unequally acted upon, it may be undermined, or several projecting ledges may be left, and these may be divided by natural fissures, so as to cause the face of the cliff to assume a variety of shapes; but a talus is soon formed which pfotects it from further destruction from this cause.

The action of the atmosphere alone, therefore, cannot form groups of isolated natural columns or perforated rocks, and carry away the debris or arrange it in parallel beaches of waterworn fragments, whose levels correspond with those at which the columns remain, or to the parts of those columns which appear to have been worn slender by the long continued action of the waves. (But if we attend to what is going on at present on these islands, we shall have little difficulty in deciphering the memorials of the past. We see columns of limestone, evidently the ruins of former cliffs, assuming the various shapes of flower-pots, towers, arches, $\&$ c., and standing on the gently shelving limestone, laid dry only at low water, and at a short distance from the permanently dry shore. They are worn away by the waves acting upon a space wifich depends upon the rise of the tide, until they become very thin at the mean level of the sea. It is thus that they so frequently assume the shape which has led to their being termed flower-pots. The limestone gives way to this incessant washing, in angular fragments, which, after undergoing attrition in the surf for some time, are finally deposited in beaches of shingle, upon the shelving limestone, at an elevation corresponding to the highest rise of the tide. Such is the process at present, and the columns, with beaches of corresponding elevation, were observed to be forming in every favourable situation.

Now the columns which occupy levels far above the reach of the sea at present, are not only exactly similar in appearance and shape to those which are forming, but are accompanied by beaches of limestone shingle, more or less waterworn, and of corresponding elevation to the worn stems or shafts of the flower-pot columns.

These appearances, I think, can only be explained by allowing, as before stated, either that the land has been raised, or that the level of the ocean has fallen. In either case the changes of level have been only a few feet at a time, with long intervals between, as is indicated by the wearings of the columns, which must have required a long period of years, and by the succession of the beaches one above another*.

* 'There is one more indication which was observed by Dr. Kelly, R.N., in the harbour of Quarry island. He there found the limestone perforated by Lithophagi at a height not reached by the sea at present, 'excepting perhaps in very high spring tides. The harbour is so well sheltered that there is ver any surf to wash this perforated ledge of limestone when the water does not otherwise rise to it. Considering all the circumstances, it is possible that the sea may attain the height of these perforations, and remain at it for an hour or two at a time, during two or three tides in a month; but it is probable that in the summer, when there are seldom gales to cause extraordinary high tides, the ledge may not be reached by the water for two or three months in succession.

Lithophagi could not possibly live in such a situation, perfectly dry and heated by the sun for weeks together. We frequently found masses of limestone on the beaches perforated by Lithophagi, the shells of which remained in the cavities, but they appeared to have been washed up by the surf, and we have every reason to believe that these animals live, either constantly submerged, or in situations which are dry only for a short time during each tide. 


\section{the Geology of the North Coast of the St. Lawrence.}

That several similar elevations of the land or depressions of the sea would be necessary to account for all the appearances on the Mingan'islands, may be inferred from the following.

We ascended several times cliffs at the water's edge, and on their summits, thirty feet above high tide level, we found beaches of limestone pebbles, more or less rounded and water-worn, which were continually falling down as the cliffs gave way beneath them, by the undermining of the waves or of the elements. In rear of the first beach I counted five or six others, each higher than the preceding, and all more or less covered with vegetation, and the higher ones with trees. The highest was sixty or seventy feet above the sea. Appearances exactly similar have been observed on Lake Huron, and described in a paper published in the Transaetions of the Literary and Historical Society of Quebec*.

Most of the flower-pots and other columns were from fifteen to thirty feet, but some exceeded forty feet in height above the plateau of rock on which they stood. They were frequently arranged in lines upon a terrace of limestone, precisely as they are forming at present, at the water's edge, out of cliffs which are washed by the waves.

In those columns which have been successively worn or scooped out by the waves at different levels, it is not unworthy of remark, that the part so worn generally corresponds, in perpendicular height, to the rise of the tides at present; thus leading to the inference, that although the level of the land or sea must have changed to produce the appearances described, yet that that change has not been sufficient to materially modify the circumstances, upon which the height of the tidal wave, in an estuary, depends.

A faithful record of the powerful effect of natural agents, in the present day, will best enable us to judge of the past. It is, on this account, that I mention an instance of the partial destruction of these rocks, during an absence of ten months from the Mingan islands. In the autumn of 1831, we noticed several remarkable flower-pot columns on the east side of Mingan island, some near the water, others considerably above its level. We were familiar with their shape and appearance, having looked at them frequently through our telescopes, and used them as stations in the trigonometrical survey. Lieutenant Collins had also examined them closely. On our return, in June, 1832, we found the heads of several of these flower-pot columns broken off by an agent, traces of which still remained. An immense bank of ice and snow was on the island, in rear of the broken columns, and was not totally dissolved on the 17 th of July, when we last saw it. This had doubtlessly been forced up during heavy easterly gales, and the pressure of the ice had broken off the heads of the flower-pot columns.

This change of level appears to me of so much interest, that I must add a few more remarks respecting it, before I proceed with my description of the Mingan islands.

In almost every part of the estuary of the St. Lawrence, we observed other appearances which we could also account for only by supposing either that the level of the sea, in the estuary and gulf, has fallen, or that the land has been elevated. In many bays and entrances of valleys near the sea, are sandy terraces at different levels, corresponding on opposite sides, and so shaped that it was impossible to resist the idea, they had once formed the margin of the ocean. I have thentioned (2. p. 89), that the rivers have cut sections through the soft strata of clay, sand, and gavel, and that the detritus which they bring down, is principally derived from these formations. I have also alluded to the resemblance between these more ancient strata and those of undoubted alluvial origin, which have been formed and are still forming at the mouths of those rivers.

* Vol. i. p. 6.-1829. 
The following additional remarks will show that resemblance in a stronger light, and have reference to the phænomena which I have described upon the Mingan islands.

Sand and gravel are the most abundant materials brought down by the rivers, and are arranged around and off their entrance, forming low points and sand bars, which rest upon clay, at, or a few feet beneath the low-water level. Many of the rivers bring down argillaceous matter also, and this lighter material is carried further by the streams, and deposited in the comparatively still water without their entrance. But as these sandy points have extended further into the sea, they have covered the argillaceous matter previously deposited, and hence it is, that we always find clay under the sand in these alluvial formations. The streams, of course, cannot place these materials above their own level or that of the sea at high water. Sand shoals, which are dry every tide, are first formed, and the action of the winds and waves does the rest. The tendency of these sands to arrange themselves in strata, was frequently observed, where small streams had cut sections through the beaches.)

In walking inland from the entrances of these rivers, we pass over low flat ground, composed of sand hills and sand beaches, covered first with grasses and shrubs, and further inland with trees. The immediate banks of the river are low sand cliffs, having their bases washed by the stream. Next succeeds a sandy terrace, rising abruptly twenty or thirty feet. Directly opposite, on the other side of the river, is a similar terrace, the cliffs on each side corresponding in elevation. Another flat succeeds, and frequently a second, and sometimes a third, the last being a hundred feet or more above the sea. / If we attend to the sections cut by the streams through these terraces, we find the cliffs horizontally stratified or nearly so, the lowest stratum visible at the water's edge or a few feet above it, being clay; but if we ascend the river sufficiently far, we find that this lowest stratum of clay occupies a level above the present ocean, and in situations where there are no gorges of valleys, which we can imagine so closed up, as to raise the waters within to a higher level. I

If, therefore, these ancient terraces and soft strata are alluvial deposits, analogous in their mode of accumulation to those forming at present, then the relative levels of the land and sea have certainly changed, let the cause be what it may.

Near the Falls of the Bersimis river, Mr. Bowen found the clay, under the sand, in thin strata, semi-indurated, and having a tendency to break into rhomboidal fragments:-a circumstance, which I shall have to mention again in similar formations.

1 Among other proofs of a change in the relative levels of the land and sea in the estuary and Gulf of St. Lawrence, is the bank of semi-indurated sand and clay at Beauport, near Quebec, full of shells, of species existing in the estuary.* This bank is far above the present level of the river. We also noticed a bank, apparently an ancient beach, containing similar shells, at the entrance of the Rivière du Loup, on the south side of the St. Lawrence, and about sixty feet above the present high water mark. It rests on the greywacke and slate rocks.

Several other instances of banks of shells at high levels, on each side of the river and estuary, have been mentioned to me, but as I have not visited the localities, I merely state the circumstance as of frequent occurrence. I believe there is much in the valley of the St. Lawrence to reward the researches of the geological traveller, who may turn his attention to these comparatively recent deposits; and $I$ am surprised that they have not attracted the attention of those who have visited the St. Lawrence, and written on its geology.

* The St. Lawrence is perfectly fresh thirty miles below Beauport, yet the species of shells in the bank mentioned, are all, or at least by far the greater number, inhabitants of salt water. They are also frequently perforated by a marine boring worm which also lives in the estuary and gulf. 


\section{the Geology of the North Coast of the St. Lawrence.}

I shall describe one more proof of a change of level, which came under my own observation, at La Petite Rivière, near St. Paul's Bay.

Between Cap Maillard and Cap de la Baie, near Quebec, the hills of gneiss, abounding in garnets and magnetic iron ore, recede so as to form an irregular crescent, the interior of which is filled with a low alluvial formation, not more than 20 feet above the rise of the highest tides. This formation consists of clay thinly covered with sand, and contains many boulders principally derived from the adjacent mountains. The clay is in thin, horizontal strata, and semi-indurated, so that it can be raised in large pieces, which are easily broken by the hand into rhomboidal slabs, from six inches to a foot in diameter. It abounds with impressions of rushes, partly filled with and stained by, brown oxide of iron, derived, by filtration, from the neighbouring hills. It contains also occasionally clam shells, similar to those existing in the river.

Everything indicates a quiet deposition, when the waters of the river had a higher relative level than at present. On this alluvial flat, the farms of La Petite Rivière are situated. At present the St. Lawrence is fast destroying this alluvial formation, not by a rise in its waters, but by a change apparently of the direction of the tidal currents, depending perhaps upon the formation of shoals in other adjacent parts of the river. Every high tide, accompanied by a strong north-east gale, washes away large portions of the fields, so that the inhabitants are driven to seek for fertile soil among the hills. This gradual destruction has been going on for many years, as I was informed by a Canadian, ninety years old, who had resided there from his youth. He pointed out to me large boulders, now lying on the shoals, dry at low water, which he ploughed around thirty or forty years before.

The old church of La Petite Rivière has been washed down by the waves, and the present one is likely to share the same fate, at no very distant period. The old church of Les Eboulemens which was built upon a similar formation, has been also destroyed in the same manner. The wall next the water has fallen, having been undermined by the waves, and trees now grow within the other three, their roots assisting to preserve the ruin. I

Such are the indications of a change of level which have come under my own observation. I must now conclude this subject with the following remarks.

I cannot affirm positively that the heights of the terraces, in valleys and bays of the main land, are exactly the same as those of the ancient sea beaches of the Mingan Islands, but there appeared a very near agreement.

It is certain that terraces of the same height extend over very large areas, and it appears extremely probable that the same agent may have simultaneously elevated these ancient alluvial terraces, and the ancient beaches and natural columns of the islands.

It is not easy to imagine any alteration in the level of the sea, within the Gulf of St. Lawrence, without an equal change in that of the Atlantic Ocean. It is to volcanic agency, therefore, we must look for the probable cause of the appearances which I have endeavoured to describe; and the probability of this inference is manifested by the fact, that the great agent alluded to is still felt. Shocks of earthquakes are frequent at Murray Bay, Les Eboulemens, St. Paul's Bay, and the adjacent country, of force sufficient, at times, to split walls, throw down chimneys, $8 \mathrm{c}$.*

The earthquake of 1663 is said to have lasted six months, and to have caused land slips and other changes in the face of the country. It is to be regretted that there are no clear and detailed

* For an account of the earthquake of 1791, see Lieut. Baddeley's Notes on the Geology of St. Paul's Bay, Transactions of the Literary and Historical Society of Quebec, vol. ii. p. 83, et seq. 1831.

VOL. V.-SECOND SERIES. 
accounts of this event; but it is sufficient for the object which I have in view, to mention the fact of its occurrence. Frequent shocks have been felt every year since, though less violent.*

I must now return to the description of the Mingan Islands, from which I have digressed so greatly in pursuing a subject, which I believe, had not been before touched upon by any author on the geology of the shores of the St. Lawrence.

8. The Mingan and Esquimaux Islands have very little soil. The limestone, where not bare, is covered by limestone shingle or gravel, or by decayed vegetable matter resembling peat. Hence the islands may be considered barren in an agricultural point of view. The timber also is small, and principally spruce, with a few birch and Canadian poplar or aspen trees. Blue or whortleberries, cranberries, and several other wild fruits are in abundance.

The stream of the tides is not very strong among these islands, seldom exceeding a mile an hour, except in narrow channels, where it sometimes attains a rate of two and a half. The rise is about seven feet in ordinary spring tides, and about three feet in neap tides.

9. The mainland is composed of low granitic hills. St. John's Mountain, some miles in rear of the entrance of the river of the same name, and 1416 feet above the sea at high water, is the loftiest point in the neighbourhood. There is land about 1000 feet high, opposite Quarry Island, ten miles east of Mingan, but towards the east end of the chain of islands the mainland is very low, the hills being far back in the country.

The granitic rocks, a few miles to the eastward of Mingan, are composed

* In July, 1831, the shocks at Murray Bay were more than usually severe. The walls of the church, it is said, were split, stone ovens and chimneys were thrown down or displaced, and a rocking motion was communicated to the houses. Many of the inhabitants were so alarmed as to seek safety on board of vessels in the bay, where the shocks were also felt. This earthquake was experienced at Beauport, nearly ninety miles to the south west: how far it extended in the opposite direction is not known, there being no inhabitants. It was also felt on the south side of the St. Lawrence, at the Rivière Oulle, and at St. Roques : how far it might have been felt to the northward of the St. Lawrence is also unknown, the country in that direction being uninhabited. An intelligent lady, who was then at Murray Bay, informed me that the shocks were always preceded by a subterranean noise, resembling distant thunder, which approached from the northward, and appeared to pass under the houses. When this noise seemed immediately beneath the house, a heavy shock was felt, as if the house had received a heavy blow; this was succeeded instantly by a rocking motion of the building and undulation of the ground, producing a sensation not unlike sea-sickness. The earthquakes have been, in general, accompanied or succeeded immediately by squally weather, sudden gusts of wind, $8 x$. Shocks were felt very frequently during the months of March and April, 1833. 
of red felspar, quartz, and hornblende, the felspar predominating. They are succeeded to the eastward, opposite St. Geneviève Island, by true granite, consisting of red felspar, white quartz, and black mica.

The connexion of the granite and limestone is well shown at several points. On the east side of Pillage Bay and Mount St. Geneviève, 332 feet above the sea, the limestone rests immediately upon the granite in nearly horizontal strata. Opposite St. Geneviève Island is a round, isolated and precipitous hill of limestone, which rests also upon genuine granite; and other similarly shaped hills of limestone, with mural sides, but smaller and of less elevation, occur in the same vicinity, resting likewise on granite.

The country for many miles inland is composed of low granite mounds, the intervening hollows being filled with stagnant water, peat, or other vegetable matter.

The great irregularity of the bottom of the sea among these islands, as indicated by the sounding lead, strengthens the inference from analogy, that the islands rest upon granitic hills, in the same manner as the isolated hills of limestone mentioned above. Some of the rocks and shoals, under the sea, are as precipitous as the islands above it, having thirty or forty fathoms of water close to them. It does not seem difficult to imagine, in this respect as well as in others, a resemblance in these ancient calcareous formations, to those which are forming at the present day, on the summit of submarine hills in tropical climates.

Neither limestone nor any other transition or secondary rock, was met with to the eastward of St. Genevieve.

10. The coast thence to Cape Whittle, in the longitude of $60^{\circ}$ west, and latitude $50^{\circ} 10^{\prime}$ north, is composed of varieties of granitic rocks, in which, contrary to what has been observed of the granites of Canada, hornblende is a rare constituent. The coast is of very moderate elevation, possesses few remarkable features, and cannot be distinguished from the deck of a vessel, at a distance exceeding four or five leagues. It is broken into bays and inlets, and lined with innumerable small islands, rocks, and reefs**.

The granite of the main and islands is almost everywhere covered with peat, full of stagnant ponds of dark bog-water. Trees become more and more scarce as we proceed to the eastward, till at last they are almost exclusively confined to alluvial formations of sand and clay, which are of rare occurrence, and, excepting at Natashquan, of limited extent.

It is not my intention to describe mineralogically the different granitic rocks which occur on this coast. Metallic minerals, with the exception of

- Few places can be imagined more barren, dreary, and desolate, than this coast, or more gloomy than the climate in which it is situated. It is girded with ice, and covered with snow, from October to June, and is wrapped in dense and cold fogs for more than two thirds of the remainder of the year: yet it teems with life in the summer season. 
iron, appear to be rare : native copper, associated with epidote, was met with by Lieut. Collins in only one instance, about five leagues eastward of St. Geneviève, and in very small quantity: schorl and traces of iridescent or Labrador felspar were observed in the same locality: and hypersthene, or Labrador hornblende, was often noticed. I sometimes imagined, that I could perceive an imperfect stratification in these granitic rocks, but it may have been the result of structure, and upon the whole I regard them as unstratified. They are traversed occasionally by trap veins, insignificant in size, when compared with the immense dykes of the Lake Superior granites, which appear to have poured forth such extensive beds of greenstone and amygdaloid, an operation which probably took place under the ocean, from the frequent association of beds of rolled masses of porphyry, cemented by a paste of the same material as those igneous rocks.

Six rivers of considerable magnitude, besides smaller streams, enter the Gulf of St. Lawrence between St. Geneviève and Cape Whittle, namely the Nabesippe, Aqwanus, Natashquan, Mushquarro, La Romaine, and Coacoatcho, and are respectively distant from St. Geneviève 33, 38, 50, 79, 97, and 110 miles. They are all unnavigable in consequence of shallows or rapids, commencing a short distance within their entrances. The Natashquan, which flows into the gulf directly opposite the east end of the Island of Anticosti, is the largest, and is remarkable for the great quantity of sand which it discharges into the sea; and its wide bed, like that of the Moisic, is full of sand-banks. Its mouth is on the west side, and near the southern extremity of an alluvial promontory, the materials of which it appears to have brought down during the course of ages.

This alluvial accumulation, formed evidently by the combined action of the river, tides, winds, and waves, is the most extensive which we have seen on the north coast of the St. Lawrence below Quebec, unless that of the River Moisic be equally so. Its area is forty-eight square miles, and it has completely covered the low granitic islets and rocks. Thus, it has not only interrupted the direction, but also completely changed the character of the coast for the distance of twenty miles, substituting cliffs of sand, or sandy clay, with a fine sandy beach in front, for innumerable islets, rocks, and reefs.

11. To the southward of the Mingan islands and along the coast of Labrador, as far east as we have yet examined, are extensive banks having from twenty to forty fathoms of water, and composed of gravel, sand, and immense quantities of broken shells. In sounding over many hundreds of square miles, fragments of shells, and occasionally of coral, were brought up, by almost 
every cast of the lead. Indeed there is nothing more remarkable than the immense quantity of calcareous matter, supplied by testaceous and crustaceous animals, in the Estuary and Gulf of St. Lawrence. The beaches were occasionally composed almost exclusively of small fragments of shells. In depths exceeding fifty or sixty fathoms the bottom was usually mud.

Another fact which forced itself upon our notice, was the frequent occurrence of the bones of cetacea along the shores, and probably, for the most part, of animals destroyed by the whalers. They were frequently observed on the low alluvial flats at the entrances of rivers, and were sometimes accompanied by marine, freshwater, and terrestrial testacea, together with the bones of quadrupeds and birds*. In such situations these remains can scarcely escape being carried away by freshets, at the periodical melting of the winter's snows, and being promiscuously deposited in the mud and sand on the bars of the rivers. May we not attribute to similar combinations of circumstances, the admixture of marine with freshwater, or terrestrial remains, in more ancient formations, where no other circumstances appear to contradict such an inference?

12. I shall close this paper with a few observations intended to complete a very rough outline of the geology of the river and estuary of the St. Lawrence below Quebec.

All the islands on the south shore of the St. Lawrence above the junction of the Saquenay, and the few below it, together with the whole of the south coast as low down as Cape Rozier, are composed of alternating strata of greywacke and slate, dipping to the southward at angles varying from about $30^{\circ}$ to nearly $90^{\circ}$.

Above Cape Chat the hills which bound the valley of the St. Lawrence to the southward, are some miles from the coast, but at Cape St. Anns, a few miles below Cape Chat, they approach the sea, and give a mountainous character to the remainder of the coast as far as Cape Gaspé.

We have ascertained, by actual observation, that the hills next the sea, as high as 1000 or 1500 feet, are of greywacke and slate. There is a higher, parallel chain a few miles back, which, in one part, is nearly 4000 feet above the sea, being the highest land in Canada or the United States, excepting the mountains of New Hampshire. This higher chain has been said to be primary and the outline or contour of the hills which compose it, lead to that inference. I doubt, nevertheless, of this being the case, because I have observed

* On the sands at the entrance of the river at Mingan, I saw the whole of these remains together. 
that the dip of the transition rocks is not changed by their immediate vicinity, and because other hills of considerable elevation and of the same appearance, have been ascertained to be of sandstone. I am inclined to think that they will be found to be of greywacke, or of secondary rocks overlying that formation.

The south coast of the St. Lawrence follows the direction of these hills, curving to the southward as we proceed to the eastward; and it is worthy of remark, that the direction of the strata seems to follow that of the coast. The greywacke series terminates on the coast at Cape Rozier, and is succeeded by conformable strata of limestone, dipping at an angle of about twenty-five degrees to the south-west, and forming the remarkable and precipitous headland of Cape Gaspé.

This limestone contains Encrinites, corals, Orthocera, Producta, and other shells similar to those found in the limestones of Anticosti and the Mingan and Esquimaux islands. It contains thin veins of galena and blende, but not worth working.

This limestone, which I conceive to be the younger transition, is succeeded to the southward, by a series of alternating sandstones and shales, the strata of which are much disturbed, but preserve a general, conformable dip to the south-west. Both the sandstones and shales are highly bituminous, and petroleum springs have been found in the neighbourhood.

Still further to the southward, at Percé, near the entrance of the Bay of Chaleur, conglomerate, sandstone, shale, and limestone were observed, alternating in conformable strata, and preserving the same general dip as before mentioned. Among these, coal is said to have been discovered, thus indicating the approach towards the extensive coal formation of New Brunswick. It is probable that we shall learn more respecting the formations of this neighbourhood, when we survey the southern part of the gulf.

I must now close the paper with a hope, that the desultory and imperfect nature of the information which it contains, will be excused, when it is considered that the remarks, here given, were the result of those casual observations, which we were enabled to make, during the prosecution of our professional duties. 


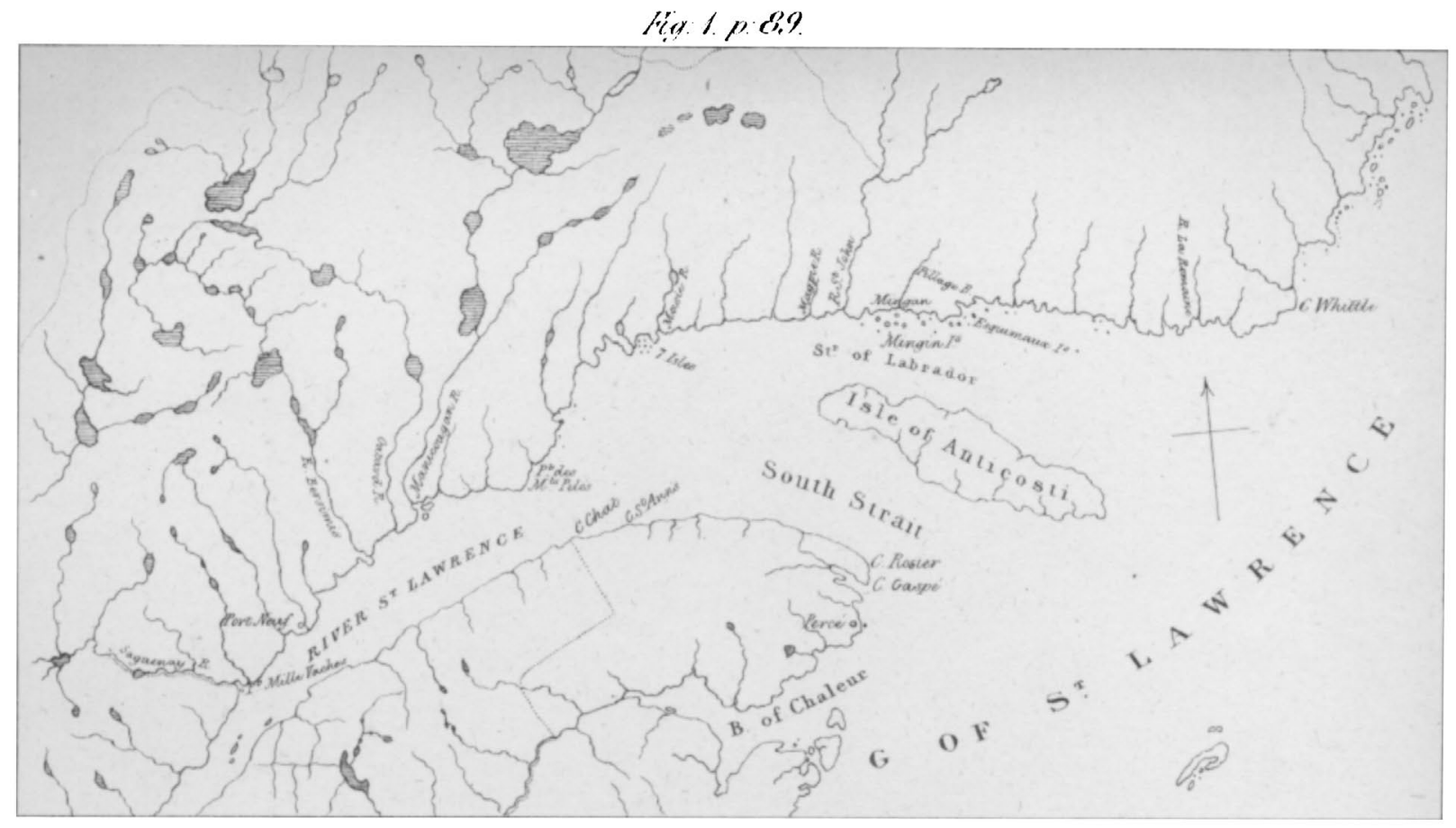

Sketch of the River and kiulf of S" Lawrence.

Fig.2p.9\%

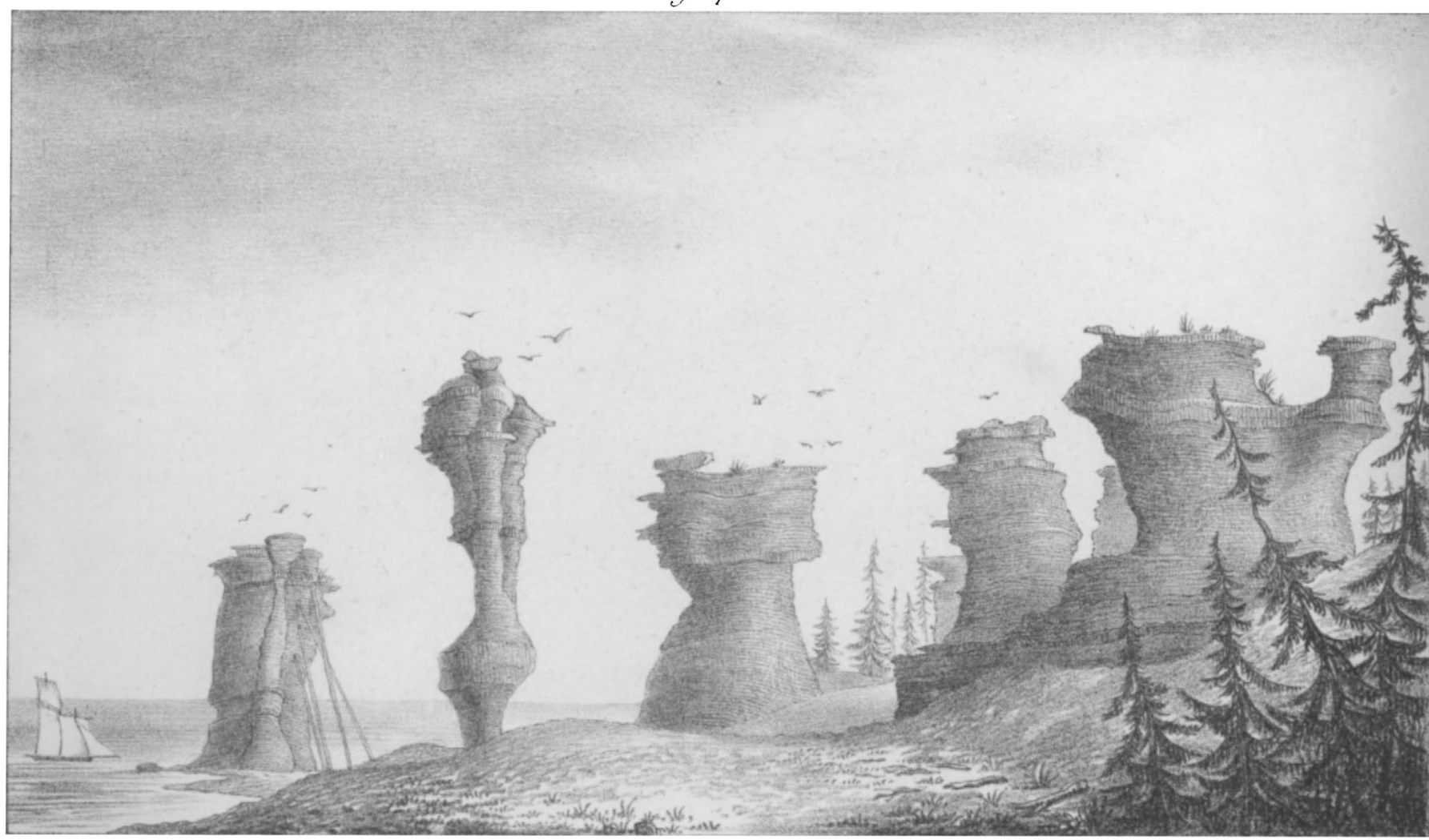

